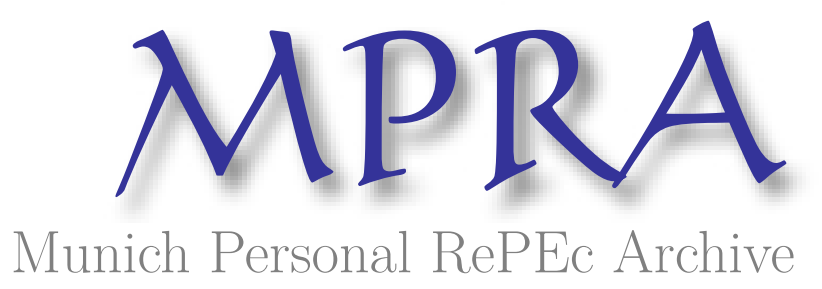

\title{
Unequal exchange: developing countries in the international trade negotiations
}

Nogues, Julio

Academia Nacional de Ciencias Economicas (argentina)

2004

Online at https://mpra.ub.uni-muenchen.de/86172/

MPRA Paper No. 86172, posted 12 Apr 2018 14:52 UTC 
CHAPTER 12

\title{
Unequal Exchange: Developing Countries in the International Trade Negotiations
}

\author{
Julio J. Nogués \\ Professor, International Trade Policies and Institutions, Universidad Torcuato Di Tella, \\ Buenos Aires, Argentina
}

Abstract

The results of the Uruguay Round, show that the concessions given by developing countries were generally more valuable than those they received from industrial countries. I suggest that this outcome is explained by aggressive demands from industrial countries, and by the lack of resources at the disposal of developing countries. These and other 'structural factors' weaken the negotiating capacity of developing countries and the outcome of their bargaining is likely to be an 'unequal exchange of concessions'. The chapter discusses the costs of these exchanges, and the structural factors that help to understand the processes leading to these outcomes.

Keywords: Latin America, Uruguay Round, reciprocity

JEL classifications: F13, F15

Developing countries have to have the courage to insist that all reasonable doubt as to the economic effects of a proposed agreement be removed before they allow a decision to be approved. (J. Michael Finger).

\subsection{Introduction}

The history of the first rounds of multilateral trade negotiations shows that the exchange of market access concessions was a process characterized by reciprocity and mutual benefits among participating countries. More recently, however, the results of the Uruguay Round, where for the first 
time developing countries negotiated actively, show that the concessions given by them were more valuable than those they received. In these negotiations, developing countries did not achieve the degree of reciprocity expected from the previous history of the trading system.

This outcome has been explained in part by increasingly aggressive demands by industrial countries and in part, by the lack of adequate resources of least developed countries. These and other 'structural factors' such as lack of negotiating experience and inadequate knowledge on economic impacts weaken the negotiating capacity of developing countries and suggest that in multilateral or regional trade negotiations with industrial countries, they are at a disadvantage. The thesis of this chapter is that these exchange of concessions are most likely to be 'unequal exchanges'.

Unequal exchanges result in unbalanced outcomes and this can have serious consequences for developing countries and the trading system. For developing countries, an unbalanced outcome as measured by the difference between the value of concessions given and received has two economic costs: (a) the costs associated with a degree of access to foreign markets that is lower than the one that would have resulted from balanced negotiations, and (b) the costs associated with the weakening of their bargaining power implied by 'excessive concessions' given in past negotiations. For the trading system, unequal exchange negotiations also have serious negative consequences. This is illustrated, for example, by the 'implementation' problems faced by developing countries in several of the Uruguay Round agreements which may have not surfaced under less unequal negotiations. These implementation problems are one of the factors that soured relations among WTO members and threatened to block the launching of a new multilateral round in Doha (World Trade Organization, 2001a).

The rest of this chapter is arranged as follows. Section 12.2 illustrates the significant gains that efficient agricultural producers could reap in international negotiations. Section 12.3 takes up the Uruguay Round as an example of a negotiation characterized by an unbalanced outcome explained in part by an 'unequal exchange' process. Section 12.4 delineates some of the elements that help to understand why some trade negotiations are likely to result in 'unequal exchanges'. It starts by presenting some of the 'structural factors' that help to understand the weak negotiating capacity of developing countries. The problems associated with this weakness are compounded by industrial countries' 'aggressive unilateral policies' and their ability to prevail in the definition of the negotiating agendas. One of these negotiations involves the MERCOSUR and the European Union and in Section 12.5, I use this case to illustrate how some 
of developing countries' handicaps appear to be operating in practice. Finally, Section 12.6 suggests some preliminary lessons.

\subsection{Economic interests of efficient agricultural producers in trade negotiations}

The interests of developing countries in the negotiations on market access are significant. As an example, I will comment on the gains that efficient producers, in general, and Argentina, in particular, could reap by negotiating with countries that provide high protection to their primary sectors and resource-based manufactures of agricultural origin. ${ }^{1}$ These are primarily industrial countries. As an example, Table 12.1 shows the pattern of protection of the European Union (EU) for selected chapters of the harmonized nomenclature. These very high levels of protection affect some of the goods where efficient producers have a strong comparative advantage. In 2000 for example, Argentina's exports of agricultural and agro-industrial products represented 21 and $30 \%$ of total exports, respectively.

\subsubsection{Agricultural protection and exports}

By how much would exports increase if this protection would be drastically reduced or eliminated? Traditional comparative static trade analysis shows that the lifting of agricultural protectionism by OECD countries would have a significant impact on exports and GDP. The most recent estimates based on the GTAP model suggest that this liberalization could increase total exports of goods by a percentage that, depending on the underlying elasticities, is at a minimum equivalent to $25 \%$ (Casaburi and Sánchez, 2000). Most of these gains would come from the liberalization of European agricultural trade (Sánchez, 2001).

\subsubsection{Agricultural protection and financial costs}

Agricultural protection also increases financial costs. To see how this happens, recall that in emerging countries with open capital accounts, the market clearing interest rate for the government and most prime companies is equal to the risk free rate plus the rate of country risk. On the margin at

\footnotetext{
${ }^{1}$ In manufactured products, the comparative advantage of Argentina is determined by its factor endowment vis-à-vis the country or group of countries with whom it is negotiating, as well as by the pattern of their protection. Thus for manufactured goods, past research shows that vis-à-vis labor-abundant (capital-abundant) countries, Argentina exports more laborintensive (capital-intensive) manufactured products (Nogués, 1985).
} 
Table 12.1. Agricultural protection in the European Union

\begin{tabular}{llcc}
\hline Chapter & \multicolumn{1}{c}{ Name } & Average Tariffs & Maximum Tariffs \\
\hline 1 & Live animals & 26.2 & 106.0 \\
2 & Meat and meat products & 33.3 & 236.4 \\
4 & Dairy products, etc. & 40.3 & 146.1 \\
7 & Vegetables & 12.0 & 140.7 \\
8 & Fruits & 9.6 & 130.4 \\
10 & Cereals & 47.3 & 179.7 \\
11 & Wheat and mill products & 24.5 & 137.8 \\
12 & Seeds, etc. & 2.3 & 67.0 \\
15 & Animal and vegetable oil and fats & 8.2 & 89.8 \\
16 & Meat and fish preparations & 18.4 & 50.1 \\
19 & Cereal preparations & 17.9 & 48.5 \\
20 & Vegetable and fruit preparations & 22.7 & 161.5 \\
\hline
\end{tabular}

Source: Table AIII.1 in World Trade Organization (2000).

this rate, foreign investors are willing to lend. Therefore, if protectionism increases country risk, then this implies that domestic borrowers are paying interest costs that are above those that would prevail under free agricultural trade.

What are the determinants of country risk? A growing number of analytical and econometric studies have analyzed these determinants and found that some of the important explanatory variables include (i) growth expectations: the higher the growth expectations of an economy, thelower the risk of investing in it; (ii) degree of solvency: the higher the burden of the debt and the lower the capacity to generate higher levels of exports, the higher the perceived degree and risks of insolvency, (iii) structural problems: the more serious the structural problems including most prominently labor-market rigidities and fiscal deficits, the higher the country risk, (iv) contagion: understood as the 'flight to quality' triggered by the 'herd instinct', also raises the country risk when other developing countries run into financial problems; and (v) political uncertainty: associated, for example, with important differences among leading politicians regarding the set of appropriate economic policies, is also expected to increase risks.

While the literature includes a number of cross-country econometric studies of the determinants of country risk, few of them have focused on single countries. In a recent paper, Nogués and Grandes (2001) studied the determinants of Argentina's country risk by using explanatory variables discussed above. In our analysis, we chose as the independent variable, the spread of Argentina's sovereign bonds (in this case, the floating rate bond or FRB), over the US treasury bond of a similar maturity. The selection of 
Table 12.2. Exports and country risk, Argentina 2000

\begin{tabular}{llr}
\hline Elasticity of Country & \multicolumn{2}{c}{$\begin{array}{c}\text { Export Losses from } \\
\text { Risk to Debt-Service Ratio }\end{array}$} \\
\cline { 2 - 3 } & 25 & 50 \\
\hline 20.5 & 10 & 17 \\
21.0 & 20 & 33 \\
\hline
\end{tabular}

the independent variable was driven by the fact that the most important debtor of Argentina is the national government.

Our study concludes that the elasticity of country risk with respect to the ratio of debt service to exports is 20.68. It also concludes that all of the other variables mentioned above have a statistically significant impact on Argentina's country risk and enter the regression with expected signs.

The estimate of this elasticity allows an educated guess of the impact of agricultural protectionism on Argentina's excess interest costs paid by both the government and the private sector. Table 12.2 shows simulation results regarding the impact of foregone exports due to agricultural protectionism on country risk. We use two values of the elasticity of country risk with respect to the debt service ratio to exports: 20.5 and $21.0 \%$. Likewise, based on the study by Sánchez (2001), I use two estimates of foregone exports due to agricultural protectionism: 25 and $50 \%$ of 2000 exports. The results of this simulation indicate that the range by which agricultural protectionism can increase Argentina's country risk goes from 10 to $33 \%$.

At the end of 2000, the stock of total debt (private and public), stood at around $\$ 280$ billions and for the year, the average level of country risk was 672 basis points. Therefore, according to the figures presented above, the excess interest costs paid by Argentina's debtors due to agricultural protectionism was at a minimum in the order of $\$ 1.9$ billion $(0.10 £ 672 £$ $\$ 280$ billion), or $0.7 \%$ of GDP, but it could also be as high as $\$ 6.3$ billion $(0.33 £ 672 £ \$ 280 \text { billion })^{2}$

\subsubsection{Agricultural protection and growth}

A higher country risk has not only a direct negative financial cost but also a dynamic negative effect as higher interest rates slow growth.

\footnotetext{
${ }^{2}$ To the extent that some of the debt carries a fixed interest rate, these estimates would need to be adjusted. However, the analysis indicates a sizable negative financial costs of agricultural protectionism that are over and above the negative effects estimated with traditional comparative static trade models.
} 
Figure 12.1. Country risk and inter annual GDP growth rate

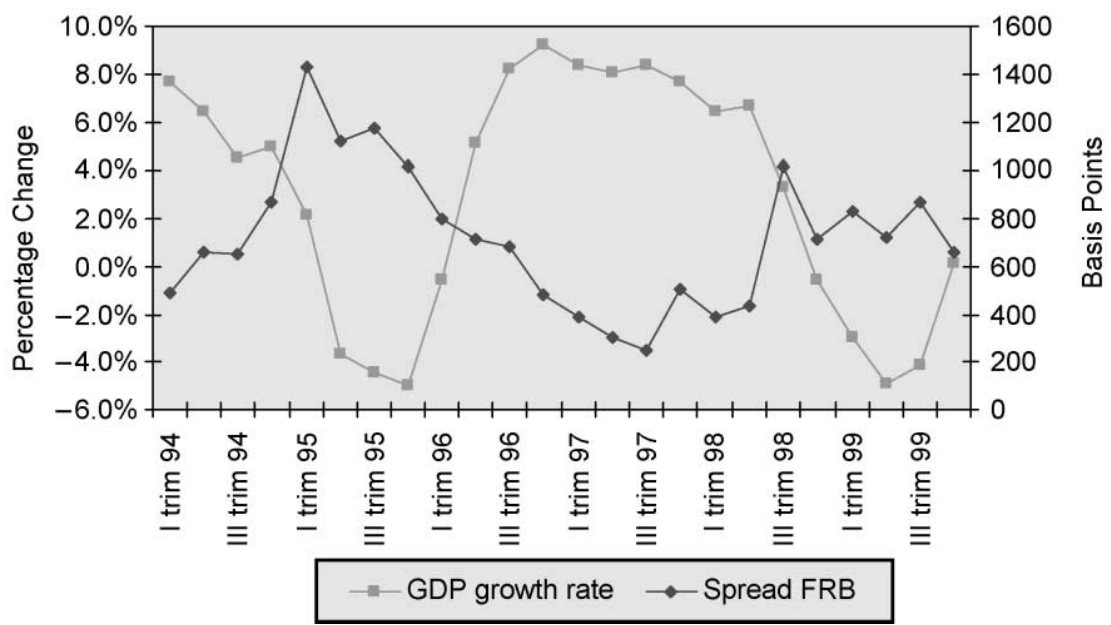

Source: Nogués and Grandes (2001)

Figure 12.1 shows a negative relationship between the level of country risk and the quarterly year to year variation of GDP. Obviously, the country's long-run growth performance is explained by other factors in addition to the level of real interest rates. This negative growth effect is reinforced by the fact that the dismantling of agricultural protectionism would improve expected export growth and therefore, expected GDP growth that in the Nogués and Grandes study (2001) has a very important effect on the level of country risk. Summing-up, the negative economic and financial consequences on Argentina of agricultural protectionism are sizable. $^{3}$

\subsubsection{Agricultural protection and export prices}

The literature has also stressed the impact of agricultural protectionism on macroeconomic instability. This is attributed to the perversity of the protectionist policies that attempt to compensate industrial countries' farmers for international price reductions. These compensatory policies

\footnotetext{
${ }^{3}$ Argentina has been in recession since early 1999 when its level of country risk began to increase steadily mainly due to fiscal imbalances and the weakening of the political base of the government. In 2001, this level was above 1000 basis points and after the collapse of Convertibility in December of 2001 it has reached and stayed at around 5000 basis points which implies that the country has been shut-off from the private financial markets. Mussa (2002) presents one of the first assessments of the financial collapse of Argentina.
} 
widen the fluctuations of international prices which in turn are transmitted as one of the determinants of the economic cycles of efficient agricultural producers. For example, between 1997 and 2000, Argentina's agricultural export prices declined by $25 \%$ while those of agricultural-intensive manufactures, declined by 24\%. Not surprisingly, between 1997 and 1999, the yearly assistance by OECD countries to their agricultural sectors increased from $\$ 328.7$ billion to $\$ 361.5$ billion. Much of this assistance was provided in order to compensate farmers from the negative income effects of international commodity price reductions. In 2000, after several years of uninterrupted growth, this assistance declined. However, the OECD analysis indicates that this reduction “....reflected international price and exchange rate movements rather than major agricultural policy changes. There were no major policy reform initiatives..." (OECD, 2001).

\subsubsection{Summing-up}

For Argentina and other efficient emerging producers, agricultural protectionism has significant costs that are above those usually estimated. I have argued that for developing countries with open capital accounts, the costs of the protectionism encountered by their products in foreign markets tends to worsen solvency indicators which in turn increases financial costs paid by residents and slows the country's growth rate. ${ }^{4}$ These effects, plus industrial countries' statements that agricultural policies could be addressed in international trade negotiations, explain the significant interests of the country and MERCOSUR (as well as other developing countries), in these negotiations as the way for reducing this protectionism. ${ }^{5}$

\footnotetext{
${ }^{4}$ Grandes (2001) provides additional evidence of the role that exports play as a determinant of country risk in other developing countries.

${ }^{5}$ However, after more than a year of multilateral discussions in the WTO, it is not at all clear that industrial countries would implement an important reduction of agricultural protection. The public relation campaign supported by the concept of 'multifunctionality' has been developed precisely to resist liberalization. Also, at the time of writing this article, the US Congress is likely to pass another generous farm bill. These actions indicate that industrial countries have been successful in 'building their case' for continued agricultural protectionism. In contrast, developing countries have shown a weak capacity to build their case in order to challenge more effectively, developed countries' protectionist goals. For example, the concept of multifunctionality could had been challenged by concepts such as 'increased rural poverty' stemming from agricultural protectionism but efforts like this have not been attempted. In spite of all, MERCOSUR continues to put hopes on multilateral and regional negotiations with industrial countries as a way of increasing its agricultural exports and improving growth performance.
} 


\subsection{The unbalanced Uruguay Round}

The Uruguay Round is the salient example of an unbalanced negotiation in terms of the value of concessions given and received by developing countries. In the context of the topic of this chapter, it is useful to recall some of the outstanding elements that account for the unbalance.

\subsubsection{The UR promise}

The launching of the Uruguay Round was heralded by most qualified observers and multilateral institutions in part because industrial countries accepted to include textiles, clothing and agricultural protection on the negotiating table. The expectation was that this Round would increase the market access opportunities faced by developing countries in developed country markets. The promise of these new trading opportunities and the lack of negotiating experience help to understand why developing countries accepted an ambitious negotiating agenda that included several 'new areas' that had not been the subject of negotiations in the previous MTNs. This agenda included services and intellectual property where comparative advantage is clearly on the side of industrial countries. Therefore, the grand exchange of concessions expected for this Round at its launching ceremony can be characterized as one where developing countries would liberalize their markets in the new areas of interest to industrial countries in exchange for increased market access in agricultural and labor-intensive manufactured products.

The UR results show a clear imbalance between the market opening concessions given and received by developing countries.

\subsubsection{The unbalanced UR outcome $e^{6}$}

In order to assess the outcome of the UR, I summarize some of the salient features of the negotiations on market access concessions pertaining to tariff and non-tariff barriers, implementation problems, services and intellectual property.

\subsubsection{Market access}

The outcome of these negotiations can be assessed in terms of (i) the proportion of imports whose tariffs are bound and (ii) the depth of the tariff cuts. Estimates show that developing country tariff bindings increased significantly in the UR, and came close to the incidence of bindings that

\footnotetext{
${ }^{6}$ This subsection draws from Finger and Nogués (2002).
} 
characterizes industrial countries which already was very high before these negotiations started (Blackhurst et al., 1996). However, most bindings are at higher levels than applied tariffs. ${ }^{7}$

Regarding the proportional depth of the tariff cuts, that of developing countries has been far more important than that of industrial countries. The reason for this is that at the start of the UR developing countries protected their markets more than industrial countries and furthermore, several of them were implementing significant unilateral liberalization programs. The proportional tariff cuts indicates that developing countries' import prices declined by a higher percentage than those of industrial countries (Finger and Schuknecht, 1999).

In regard to non-tariff barriers, the analysis of this UR obligation shows that developing and industrial countries have generally complied with this obligation. In this area, there are no major differences between industrial and developing countries. ${ }^{8}$

The market access negotiations included topics where developing countries could expect to achieve some form of a balanced outcome. The promise that this would be the case is probably the most significantreason why developing countries supported the UR negotiations. The fact that in these negotiations many of them did not achieve their goals implies that in the other topics where industrial countries appear to have comparative advantage, the imbalance could only be deepened. In what follows, I concentrate on implementation issues, services and 'intellectual property'.

\subsubsection{Implementation issues}

Implementation issues include the problems faced by many developing countries in trying to comply with some UR agreements including the Agreement on Custom Valuation, the Sanitary and Phtosanitary Agreement, the Agreement on Technical Barriers to Trade and the Agreement on Trade Related Intellectual Property Rights (TRIPS). Compliance with

\footnotetext{
${ }^{7}$ As developing countries need to stabilize their trade policies, these bindings entail benefits even if unrequited. Nevertheless, according to tradition and the GATT rules, even in tariff bindings developing countries should stand firm and demand reciprocity.

${ }^{8}$ Furthermore, while the concessions given by developing countries have already been implemented, industrial countries' concessions still have to be completed (case of textiles and clothing), or still has to be negotiated (case of agriculture). The market access concessions given by developing countries, and driven mainly from unilateral liberalization efforts, have in many cases accelerated their trade and output growth. The dark side of the UR imbalance is not here, but in the continued protectionism of industrial countries in sectors of the greatest interests to developing countries and also to them as illustrated, for example, in Hufbauer and Elliot (1994).
} 
these agreements require investment in capital goods, buildings, and skills. A preliminary assessment indicates that in order to comply with these obligations, some developing countries have to make investments that are higher than their combined development budget (Finger and Schuler, 2000).

At the UR, there was no reflection on development needs, development stages or development priorities. In many cases, industrial countries standards became the 'international norm'. Pulling the string has created serious tensions in the trading system and the hypothesis of this chapter is that these problems could had been avoided if negotiations would had been less unequal.

\subsubsection{Services}

In most services (not all), it is the industrial countries that have the comparative advantage to supply them. For example, many services are essentially non-tradable and in order for them to be supplied, they require foreign direct investment (FDI). Statistics show that these FDI flows have come mainly from industrial countries. For these services which include areas such as power generation and distribution, gas distribution, telecommunications, water supply, finance, etc., industrial countries sought the 'right of commercial presence' and many developing countries binded important concessions of this type (see Hoekman, 1996; Nogués, 2001 for a more detailed discussion of Argentina). As a partial exchange to these valuable rights to 'commercial presence', developing countries sought to achieve concessions in the area of 'movement of persons' but industrial countries have refused to negotiate this topic.'

Again, the bad side of the services negotiations is not the liberalization implemented by developing countries in order to attract FDI. Given lack of capital and technical skills that characterize most developing countries, if well regulated, these flows of FDI are expected to have improved the efficiency of their economies. The bad side is that the concessions that were given were unrequited. This bad side is made even worse by the fact that apparently, WTO bindings were not an important factor in attracting FDI flows to service industries (Finger and Nogués, 2002).

\footnotetext{
${ }^{9}$ Note the abysmal imbalance between the multilateral rules that govern international capital movements, the abundant factor of industrial countries, with those that govern labor movements, the abundant factor of poor countries. On the huge differences in international migration flows and the rules that govern them see Lindert and Williamson (2001).
} 
12.3.2.4. Intellectual property: the case of patents

\section{for pharmaceutical drugs}

The 'agreement' on TRIPS was pushed by industrial countries against the opposition of several developing countries. This occurred against the lack of theoretical and empirical analysis showing that policy reforms induced by the TRIPS will increase world welfare, or the welfare of developing countries.

TRIPS covers several 'intellectual property' topics. Given the size of the pharmaceutical market and the economic interests at stake, I concentrate remarks on patents for pharmaceutical drugs. ${ }^{10}$ At the time of the UR, the World Intellectual Property Organization (1988) listed 48 countries, most of them developing, as not providing patent protection for pharmaceutical drugs. Argentina and Brazil have been included in this list. In the event, all contracting parties to the GATT/WTO signed the single undertaking UR agreement that included the TRIPS stipulating that patents should be available to innovations in all activities, and should last 20 years from the date of filling.

The patent section of the TRIPS has more to do with the issue of appropriations of the rents generated in developing countries than with concerns regarding their innovation and growth potential. In countries with a sizable share of the pharmaceutical market supplied by domestic companies like Argentina, Brazil and India, the introduction of patents will result in a significant transfer of rents to industrial countries' pharmaceutical companies (Nogués, 1993). ${ }^{11}$

Finally, it is of interest to recall that as late as the 1970s and 1980s, several industrial countries still did not provide patent protection to pharmaceutical drugs. For example, France introduced patent protection for pharmaceutical drugs in 1960; Germany in 1968; Japan in 1976; Switzerland in 1977, and Sweden and Italy in 1978. In these countries,

\footnotetext{
${ }^{10}$ Pharmaceutical drugs is one of the industries for whom patent protection is important as an incentive for investing in R\&D. Pharmaceutical drug companies have one of the highest ratios of R\&D to sales and most drug products can be easily copied. Nevertheless, given that the average costs of marketing a successful drug stands in the hundreds of millions of dollars (some estimates put it in the order of $\$ 400-500$ million) there are very few enterprises if any from developing countries with the financial strength to undertake R\&D activities at this scale. This is why in this industry, patents in these countries will most likely, not result in greater innovation.

${ }^{11}$ A recent estimate based on data for 2000, suggests that Argentina could end up transferring rents from granting patents to pharmaceutical drugs in the order of $\$ 425$ million per year (Nogués, 2001). Since October 2000, when Argentina began to grant these patents, these rent transfers have begun to increase.
} 
patents were introduced when the size of their pharmaceutical drug companies was such as to make the likelihood of drug innovation from investments in R\&D high. Patent protection was implemented somewhere along the development process and it was always a domestic policy decision taken without regard to foreign interests. For developing countries after TRIPS there is no such independence. For them the adjective has been 'pirates' and on this word, an intelligent public relations campaign was built by international companies. ${ }^{12}$

\subsubsection{Broken promises and principles}

The 1986 Ministerial Declaration that launched the Uruguay Round is an example of political correctness. Where promises had to be made they were made and where principles had to be listed they were listed. The problem came later when the outcome of the negotiations showed that significant promises and principles had been broken. If there is a new multilateral round, the lesson is that promises in the Ministerial Declaration do not matter that much. What in fact will matter is the capacity of developing countries to oversee that promises and principles be respected because there is no one who will do the job for them. Reminding some examples from the UR will help to illustrate.

\subsubsection{Promise of agricultural liberalization}

The 1986 Ministerial Declaration asserts that "Negotiations shall aim to achieve greater liberalization of trade in agriculture and bring all measures affecting import access and export competition under strengthened and more operationally effective GATT rules and disciplines...by improving market access through inter alia, the reduction of import barriers...". The data and sources cited above indicate that this did not occur. What happened?

Some of the core elements of the Agreement on Agriculture included the substitution of non-tariff barriers by ad valorem tariffs equivalents and for industrial countries, the reduction of these tariffs by $36 \%$. Analysis undertaken on the substitution of NTBs with tariffs suggest that developed countries used the opportunity to declare base tariffs of their UR obligations

\footnotetext{
${ }^{12}$ Before the TRIPS, developing countries in particular granted patent duration of differing length, and in some industries including pharmaceutical drugs, where the satisfaction of basic needs was an important consideration, they also distinguished between process and product patents. Clearly, different countries decided their structure of IPRs policies in terms of what they perceived to be in their interest in much the same way as most developed countries have always done.
} 
that in general were higher, sometimes several times higher, than the ad valorem equivalents. In fact, there have been instances where the height of tariff declared to the WTO were such that their reduction by $36 \%$ would imply tariff rates that today are higher than the ones prevailing before the UR. These 'dirty tariffs' were the norm and not the exception (Hathaway and Ingco, 1996). ${ }^{13}$

\subsubsection{Transparency}

On transparency, the 1986 Ministerial Declaration asserts that: "Negotiations shall be conducted in a transparent manner...". In many cases, transparency was not there. The agricultural dirty tariffs are one example. A second example is found in the implementation of the Agreement on Textiles and Clothing (ATC). While this agreement has complied with the promise in the Ministerial Declaration that the textiles negotiation should seek "the eventual integration of this sector into GATT...", the obscure part has been in the implementation where some countries have liberalized much less than the notional liberalization indicated in the ATC. ${ }^{14}$

\subsubsection{Reciprocity}

On this, the Ministerial Declaration included the following language under Section B on 'General Principles Governing Negotiations':

"Balanced concessions should be sought within broad trading areas and subjects to be negotiated in order to avoid unwarranted cross-sectoral demands". Furthermore, “...the developed countries do not expect the developing countries, in the course of trade negotiations, to make

\footnotetext{
${ }^{13}$ A puzzling question is why did the Cairns Group allow this to happen? The story I have been told by an Argentine trade negotiator is that notification of the tariffication exercise to the WTO was delivered shortly before the deadline. After more than 7 years, negotiators wanted to wrap-up and there was no interest or spirit in adding another round of exercises and perhaps negotiations, on what had been a protracted round.

${ }^{14}$ The problem lies in the meaning given to the expression 'integrate into the GATT' which is to certify that a textile or clothing product is clean of restrictions to trade such as quotas that for other manufactured products are illegal under the GATT. According to the ATC, the indicated proportions are applied to 1990 imports from a list of textile and clothing products that runs some 30 pages long. During the first stages, countries can choose which products in the list they 'integrate into the GATT'. This list includes the products where at least one industrial country has chosen to protect with GATT illegal instruments under the MFA. Since not all countries protected all of the products in the list, they can choose to integrate into the GATT those products which they were not protecting with quotas. As a result, so far liberalization by industrial countries has been smaller than the notional $33 \%$ that should had been liberalized by now (Finger and Nogués, 2002).
} 
contributions which are inconsistent with their individual development, financial and trade needs...".

This section has argued that reciprocity, in the tradition of the first seven rounds of the GATT, was not there.

\subsubsection{Summing-up}

The UR broke with the GATT principle of "...reciprocal and mutually advantageous arrangements ..." (Preamble to the GATT). This was the first multilateral round where developing countries participated actively and the results show that even in market access concessions many of them including the efficient agricultural producers, never came close to achieving a balanced exchange. The imbalance in market access was worsened by (i) agreements requiring socially unprofitable investments in order to comply with 'obligations', (ii) unrequited concessions in services as still no agreement has been reached to regulate the 'movement of persons', and (iii) forced adoption of specific intellectual property standards. Two major factors appear to explain this imbalance: developing countries' structural negotiating weaknesses interacting with historically aggressive demands by industrial countries. These and other factors, discussed in greater detail in Section 12.4, help to understand why the UR represented the milestone example of 'unequal exchange' in international trade negotiations between industrial and developing countries. Finally, in order to reach an unbalanced UR outcome, important promises and principles of the multilateral system had to be broken.

\subsection{Management, knowledge, agenda and other handicaps of developing countries in international trade negotiations}

In this section, I summarize some of the handicaps that developing countries face in the international trade negotiations. Most of the comments draw from the experience of Argentina and in some instances, other MERCOSUR countries. Certainly not all of these handicaps characterize other developing countries but some could be quite extended and further research could offer more general findings.

The negative consequences of developing countries' handicaps are compounded by industrial countries' clout to set the negotiating agenda, and by what has been called, their 'aggressive unilateralism' both of which are discussed briefly in Section 12.4.2. The Section 12.4.3 includes some tentative conclusions. 


\subsubsection{Some developing countries' handicaps}

In what follows, I will discuss handicaps associated with the following issues: (1) experience and domestic managerial arrangements, (2) the pros and cons of negotiating as a member of a trade agreement, (3) lack of knowledge on economic impacts of reciprocal concessions in different areas, (4) role of the private- public sector linkages, and (5) the impact of financial problems on trade negotiations.

\subsubsection{Experience and management arrangements}

Many developing countries have given the responsibility of administering the trade negotiations to their Foreign Affairs Ministries and in some cases, this may have weakened the negotiating strength. First, in the new agenda of trade negotiations, tariffs and non-tariffs barriers are only two of the items on the table. Had trade negotiations remained focused on these barriers, the decision on which ministry is responsible for the negotiations would not had been that serious. But as seen, the negotiating agenda that has been expanded considerably since the Uruguay Round and now includes a number of topics where concessions granted sometimes may result in net costs and concessions received in these same areas could be of not much value. Diplomats have not been trained to assess the economic dimensions of the increasing number of items that are being included in most negotiating agendas with industrial countries. As a consequence, they are more likely to agree to unbalanced outcomes. ${ }^{15}$

Second, most career diplomats are lawyers by training and they do not necessarily share the same kind of concerns that economists and entrepreneurs might have as they observe a negotiation becoming unbalanced. Reaching agreement in a negotiation is usually higher in the ranking order of priorities of a Foreign Affairs Ministry, than walking away from a meeting because a balanced and mutually beneficial negotiation is not being reached. This is more likely to occur when those sitting on the other side of the table have 'political clout'.

\footnotetext{
${ }^{15}$ Obviously, the Ministries of Foreign Affairs are advised by other government offices. The problem here is that most of these other offices also have no experience in dealing with trade negotiations and often they feel removed from the long-run consequences of the advise they may give. In practice, therefore, except for institutionalized interactions with the Ministries of Economy, the Ministries of Foreign Affairs often decide by default.
} 
Third, the structure of incentives in their careers, implies that diplomats usually are keen to obtain a foreign assignment as local wages are generally lower than those they receive abroad. Under these circumstances, it is a challenge to train diplomats with the goal of transforming them in the elite negotiating group of the country. As career diplomats, sooner or later they will want to leave for a foreign assignment.

Finally, Argentina and most developing countries have practically very little experience with international trade negotiations. I have no doubt that over time the Foreign Affairs Ministries will gain experience, but say 10 years from now most of the international negotiations now under way will most likely have been concluded. ${ }^{16}$ For these negotiations, the experience gained by then will have come too late.

\subsubsection{The pros and cons of negotiating as a member of a trade agreement}

In some of the trade negotiations including those with the EU and in the free trade agreement of the Americas (FTAA), Argentina negotiates as a member of MERCOSUR. This has one strength and one handicap. On the positive side, the fact that in the WTO Brazil has still to bind economically important concessions in areas such as services and intellectual property implies that the other members are assisted by Brazil's bargaining chips. The extent to which this edge is of value also depends on the capacity of Brazil to internalize the gains from the concessions it will be giving.

On the negative side, in the negotiations of the FTAA and with the EU, the MERCOSUR members have shown divergent preferences. The reason apparently lies in the differences in economic structures and patterns of comparative advantage. Paraguay and Uruguay are more specialized economies than Argentina and Brazil which shows, for example, in the concentration of trade. Thus, while in 2000 the first five products accounted for $28 \%$ of Argentina's exports to the EU, in the case of Uruguay they accounted for $49 \%$.

The consequence of this is that Paraguay and Uruguay are willing to close a trade deal with fewer concessions received than is the case for Argentina and Brazil. While a few quotas and tariff concessions might

\footnotetext{
${ }^{16}$ For a country like Argentina, the list includes MERCOSUR- EU, MERCOSUR- US, MERCOSUR-FTAA, MERCOSUR-Andean Community and the new Doha multilateral round.
} 
create important export opportunities for the first two countries, for Argentina and Brazil, it takes more to arrive at an attractive deal. ${ }^{17}$

\subsubsection{Knowledge and trade negotiations}

As said, for trade in goods, the meaning of a balanced exchange is quite straightforward, but in other areas including services, intellectual property and many others, the impact of reciprocal concessions is not known and economic assessment is not straightforward. As far as I have been able to informally assess this problem, many if not most developing countries are negotiating without an economic assessment of the probable economic consequences of the agreements they may end up signing. This contrasts with the situation of industrial countries that apparently know with precision what they want to achieve in the negotiations. These specific objectives are defined in close consultations with interest groups and in many cases they are supported by a good understanding of economic costs and benefits. This knowledge comes not only from academic research but also from government-financed analysis and what is probably most important, from a long experience of close collaboration and exchange of ideas between the private and public sectors (Dam, 2001).

\subsubsection{Private sector-public sector linkages}

Many developing countries have no tradition of holding consultations among public offices and between the public and private sectors for defining positions for the international trade negotiations. In the Uruguay Round many countries acted more from the basis of binding unilateral reforms than from the basis of negotiating an exchange of concessions. Now these countries find themselves in the midst of several negotiations without the required institutionalized mechanism for private sector-public sector consultations. Under present conditions, where many developing countries no longer have a clear public support for unilateral reforms, the absence of an appropriate consultative mechanism could become a delicate problem. To see why, consider that the MERCOSUR has entered into an

\footnotetext{
${ }^{17}$ The media has reported several instances where these differences apparently show up. Take for example the Presidential statements on the occasion of the first meeting for a MERCOSUR- US agreement also known as the $\$ 1$ negotiations. Thus, in an article published by 'La Nación' entitled 'Dividió al MERCOSUR la oferta de Washington' (August 24, 2001), while President Cardoso is quoted as saying that “...if the US presents good proposals, we will accept immediately an agreement, but if it doesn't do so, we will never accept an agreement...”, President Battle from Uruguay is quoted as having said that he “...strongly favors a MERCOSUR- US agreement...".
} 
important number of international trade negotiations at a moment where the economies of the region are characterized by declining economic conditions coupled with very high unemployment rates. This in itself puts the private sector on guard against governmental decisions in trade negotiations.

Because of this and other factors, the mandate of the private sector to go ahead with ongoing trade negotiations is not all that clear. This position plays well with some of the trading partners with whom Argentina and MERCOSUR are negotiating. In contrast, Odell (2000) considers that a strong backing by the private sector of the US negotiators has been a key issue in explaining many of its negotiating successes.

\subsubsection{Financial problems and trade negotiations}

Many developing countries are facing difficult debt repayment problems which sometimes can become interlinked with international trade negotiations in ways that are not the best for the multilateral trading system or the individual countries. For example, during 2001, in its road to disaster, Argentina walked into the IMF headquarters more often than ever before as successive financial arrangements failed to convince the international capital markets that things were moving in the correct direction. In their efforts to send positive signals, thefinancial negotiators sought a bilateral trade agreement with the US and under the pressing economic conditions, they concluded that any deal which could offer a signal that exports and GDP will soon start growing was good. For these negotiators, the sooner an agreement was signed the better quite irrespective of the its 'content'. In the end, things did not work either on the finance or the trade side, but if they would had worked, it is likely that the trade agreement would not had been the best for the country simply because it would had been negotiated under a pressing debt and financial situation that was not receptive to trade negotiations in the interests of the real economy. In any case, I believe this example illustrates the existence of circumstances where developing countries' trade negotiations can be weakened by pressing financial problems.

\subsubsection{Summing-up}

The previous comments illustrate some of the negotiating handicaps that can characterize developing countries and it is apparent that some handicaps are serious enough to merit a reappraisal of how they should approach the trade negotiations. Some of these elements are specific to some countries while others could be of a more general nature. These 
include lack of negotiating experience and appropriate economic knowledge of reciprocal concessions in most areas of the trade agenda. These and other handicaps require more research and if the hypothesis of this chapter is confirmed, then the international community has to reassess the wisdom of calling developing countries to participate in international trade negotiations without them been adequately prepared to sit at the table.

\subsubsection{Aggressive unilateralism and negotiating agendas}

In all of the areas mentioned above, industrial countries hold positions that result in a negotiating edge over developing countries. There are two other issues increasing their relative negotiating advantage: aggressive unilateralism and the ability of industrial countries for setting the negotiating agendas.

\subsubsection{Aggressive unilateralism: the case of patents for pharmaceutical drugs}

How did TRIPS came to be? The answer probably varies according to different types of 'intellectual property' protected by this agreement. As in the previous section, I will concentrate my remarks on patents for pharmaceutical drugs.

Apparently, the main reason why the patent section of the TRIPS agreement is what it is, can be traced to the power of rent-seeking groups including the multinational pharmaceutical drug companies. How did this occur? In March 1987, only a few months after the UR had been launched, Mr. Gerald Mossinghoff, then President of the US Pharmaceutical Manufacturers Association (PMA), declared that they were working with the US Congress to get it to enact “...the intellectual property revisions of the Omnibus Trade Bill that would strengthen the hand of the US Government in urging all our trading partners to respect our rights in inventions and trademarks...", (Mossinghoff, 1987), Shortly after, the Omnibus Trade Act of 1988 was passed which among other things adjusted Section 301 of the 1974 Trade Act in the direction of making it easier to introduce retaliatory trade measures based on "....unfair practices of foreign governments which can be unjustifiable, unreasonable, discriminating or which burden or restricts US commerce...".

According to the legislation, lack of patent protection is an example of an 'unfair practice', and at the request of the PMA, supported now by the new 'strengthened hand' of the US Government, the USTR initiated a series of retaliatory actions, or threatened to retaliate against several developing countries that did not provide patent protection for 
pharmaceutical drugs. These included Argentina, Brazil, Korea, India, among others.

Section 301 and its clones have been called aggressive unilateralism (Bhagwati and Patrick, 1990). Powerful economic groups have shown the ability of convincing legislators that money redistributed to them by forcing 'appropriate intellectual property legislation' around the world, is money well redistributed. In this sense, 301 is no different than the rents internalized by agricultural or textile protectionism. There is no way that developing countries can confront successfully aggressive unilateralism and when it is present at the negotiating table as it was during the Uruguay Round, the negotiations become unequal exchanges. The stick supporting TRIPS created serious problems and is a clear example of what can happen when some countries are forced to introduce policies with negative consequences for their development process. The problems were so serious that at one point they threatened to derail the launching of a new round in Doha. It was only after the Ministerial Declaration on public health had been agreed following a very firm stance by a group of developing countries, that the round could be launched (World Trade Organization, 2001b).

\subsubsection{Negotiating agenda and ambitious demands}

The UR broke the successful GATT tradition of keeping the negotiating agenda focused on market access issues. As said, in this round the agenda began to be expanded to fit the interests of industrial countries' powerful economic groups. ${ }^{18}$ In contrast, negotiations among developing countries are not characterized by this heavy agenda or if they include items other than market access, among themselves they are given plenty of time for implementation. For example, the agenda of the ongoing MERCOSURAndean Group free trade negotiations only covers trade in goods and within MERCOSUR, the goal of liberalizing services, is to be achieved in the long run.

Beyond trade in goods, there appears to be no single item in the 'new' and expanded agenda where developing countries have a clear comparative advantage. As said above, this is an a priori that can only be cleared with country-specific studies. If true, this would imply that in the 'new agenda for international trade negotiations', the likelihood that developing countries could reach balanced and mutually beneficial

\footnotetext{
${ }^{18}$ Exactly what processes explain this expansion is not clear to me. One place to look at in the US must be the process of 'getting the votes for fast track' where powerful lobbies play a successful game (Dam, 2001).
} 
agreements with industrial countries is very low. This comment applies to multilateral and regional negotiations alike. ${ }^{19}$

Not only the agenda but also the demands within each of the agenda items are ambitious. Take for example the case of services and intellectual property. In services, “...the US believes that FTAA countries should negotiate liberalization according to a top-down (negative list) approach, whereby all sectors are liberalized except where a particular FTAA country negotiates a reservation for a particular sector or measure..." Furthermore, the "...United States excludes immigration policy and access to employment markets from the scope of the services chapter of the FTAA agreement...". Certainly, a very ambitious demand that is nowhere counteracted by an equally aggressive demand by the Latin American countries (http://www.ustr.gov/regions/whemisphere/ services.html).

In the patent section of the intellectual property negotiations, the US proposal requires "...FTAA countries to grant pharmaceutical patent holders an extension on the term of their patents to compensate for any unreasonable delay in obtaining marketing approval of their product...". Furthermore, the US proposal requires FTAA countries that "...holders of rights be able to recover profits from infringers..."; that government agencies be given the "...authority to seize suspected pirated and counterfeit goods...", and that "...maximum criminal fines are high enough to deter and remove the incentive for infringement..." (http://ustr.gov. regions.whemisphere/intel.html).

Summing-up, the Uruguay Round implied a significant shift from the GATT trade negotiating agenda. Both in the multilateral and regional trade negotiations the contents of this agenda, driven mainly by industrial countries' interests, continues to be expanded. This implies that trade negotiations are more likely to result in unbalanced outcomes against developing countries.

\subsubsection{Tentative conclusions}

Developing countries bring to the negotiating table what appears to be serious structural weaknesses. In some cases, they simply do not have

\footnotetext{
${ }^{19}$ Take for example, the FTAA. The initial agenda agreed in the 1995 Ministerial Meeting covered the following items: market access (including non-agricultural tariffs and NTBs, rules of origin, customs procedures, standards and safeguards), investment and, antidumping and countervailing duties. More recently, the agenda has been expanded to include: government procurement, services, intellectual property, competition policy and dispute settlement. The Doha agenda is equally or more complex.
} 
the resources that are necessary even to attend the discussions. This extreme example of 'unequal exchange capacity' characterized the situation of several least developed countries during the Uruguay Round negotiations (Blackhurst et al., 1999). Apparently, these countries were asked to sign by the cross and were told that at a later date they would receive technical assistance explaining them what it was all about. ${ }^{20}$

While more advanced developing countries are in a better resource position, they are also handicapped from what appears to be other weaknesses associated with their development stage and lack of experience. A closer look suggests that there is some room for improvements including management structure and arrangements for the international trade negotiations.

There is also a significant vacuum in the knowledge of probable economic effects of exchanging concessions on the vast array of issues on the table. I fear that this is a handicap that characterizes many developing countries and if so, they are negotiating blindfolded. In this area, more research is urgently needed to document this gap but developing countries could start now investing in necessary knowledge on trade impacts.

A third area to look at is the linkages between the private and public sector, which also represents a barrier for negotiating effectively. Reforms have to be supported politically and for those induced by trade negotiations, this requires an efficient public sector- private sector consultative mechanism which many developing countries must still develop.

Compare this picture with the apparent situation in the US taken from the FTAA negotiations: "The US positions were developed with input from the full range of federal executive branch agencies...Advise from non-governmental sources has been obtained primarily through the formal private sector advisory committee system...The US International Trade Commission has performed the economic analysis of the probable economic effects of an agreement" (http://www.ustr.gov). Clearly these differences indicate the existence of a big gap in organizational arrangements and knowledge between industrial and developing countries.

If developing countries can strengthen some of the above-mentioned areas, they will be in a stronger position to demand reciprocity where it corresponds. They will also be in a better position to put on the negotiating table the topics that are of their interest and if they cannot prevail, at least they will be better prepared to confront ambitious demands for trade concessions.

\footnotetext{
${ }^{20}$ In many cases, this assistance never appeared or has been clearly inadequate.
} 


\subsection{MERCOSUR-EU negotiations: unequal exchange in the making}

The purpose of this section is to illustrate how the handicaps discussed in Section 12.4 appear to be operating in practice. For this I resort to the MERCOSUR- EU negotiations that are currently under way. I start by providing a brief background of these negotiations.

\subsubsection{Background}

In December 1995, MERCOSUR and the EU signed an interregional cooperation agreement, that seeks to create a trade zone. Since then, both regions have held a number of meetings and in 1999 the Cooperation Council, the highest level body of this agreement, launched the preparatory work for the negotiations. This work is undertaken by the Biregional Negotiating Committee (BNC) which has already met seven times. The first three meetings dealt essentially with exchanging information and clearing questions. The fourth meeting of the BNC (BNC IV) held in Brussels was more substantive in character. Here, the MERCOSUR informed that in the negotiations, it was seeking a free trade agreement expressing in this way its goal that the Common Agricultural Policy (CAP) should not be an obstacle for establishing a free trade agreement. In turn, the EU expressed that it was working with the goal of presenting to MERCOSUR in the BNC V, a concrete request and offer for market access. This proposal would later show to be far from a free trade agreement.

\subsubsection{Differing negotiating goals and strategies}

Between BNC IV and BNC V, MERCOSUR drafted adocument defining its negotiating position while the EU completed the preparatory work for presenting its proposal at the July 2001 meeting. The MERCOSUR document titled 'Modalities for the Tariff Negotiations', demanded, in line with its goal of establishing a free trade area, that “...it is necessary to establish a reference tariff on the basis of which liberalization would be negotiated...". It further stated that “... specific tariffs, mixed tariffs and any other type of tariffs be transformed into an ad valorem equivalent that for negotiation purposes, would be the maximum reference tariff...". In reciprocity to this, the MERCOSUR offered to dismantle its common external tariff (CET) that is defined on 
an ad valorem basis, plus any modifications introduced after its establishment in $1994 .^{21}$

Obviously, in its request to the EU for tariffication, the goal of MERCOSUR was that the many trade measures protecting EU agricultural and agro-industrial products should not be an impediment for the negotiations. In essence, by proposing to base market access negotiations on transparent equivalent ad valorem tariffs and to negotiate their dismantling in 10 years, MERCOSUR was offering full reciprocity. In fact as we shall see, it was offering more as it was not rejecting to negotiate other issues put on the table by the EU, some of which could be of doubtful economic interest to the region.

In contrast, the EU never accepted to negotiate on the basis of equivalent ad valorem tariffs. It argued that this would go against the $\mathrm{CAP}$, which it has consistently argued, is only prepared to negotiate in a multilateral round. ${ }^{22}$ MERCOSUR in turn argued that its goal was to put the regional negotiations on an equal footing for both sides, and not to challenge the CAP. In fact, the EU strategy has been to take the MERCOSUR to a situation of negotiating specific elements of the CAP on a product-by-product basis. The differences between the MERCOSUR proposal and that of the EU are significant.

\subsubsection{The EU proposal}

At the July 2001 meeting, the EU presented its proposal. In contrast to MERCOSUR's offer for a free trade agreement, it is difficult to see how the EU proposal could had been more mercantilist. The following are some characteristics of this proposal:

(a) Both sides should dismantle ad valorem tariffs in a period of 10 years but as we shall see this proposal hides an important imbalance in market access concessions.

(b) With this proposal, the EU ensures free access to the MERCOSUR market for manufactured products, the most protected sector of

\footnotetext{
21 The document presented suggestions regarding other 'technical' aspects of the negotiations. Probably the most important among these other issues was that MERCOSUR agreed to follow the EU proposal that the agreement could be implemented in 10 years.

${ }^{22}$ In Nogués (2002) I argue that it is very unlikely that the Doha Development Round will result in important rather than cosmetic agricultural trade liberalization of OECD economies.
} 
the economies of the region, in exchange for what is already a very open EU market.

(c) In agricultural and agro-industrial products the story is very different. Except for few countervailing measures, agricultural protection in MERCOSUR is also based on ad valorem tariffs. Therefore, the EU proposal to dismantle ad valorem tariffs would also imply a high degree of access to the MERCOSUR market for their agricultural products but not vice versa.

(d) Based on equivalent tariffs, Table 12.1 showed the high levels of protection granted by the EU to agricultural and agro-industrial products where MERCOSUR has comparative advantage. In addition to ad valorem tariffs, the EU imposes seasonal tariffs, specific tariffs, mixed tariffs, export subsidies, budget support, tariff escalation, special agricultural safeguards and quotas. ${ }^{23}$ Among all of these policies, the EU has offered to dismantle only the ad valorem tariffs. How significant is this offer to dismantle ad valorem tariffs? Not very significant.

(e) The EU agricultural and agro-industry policies are an example of high protection administered in a very intransparent way. It can take several months to gain a detailed knowledge of this protection and then: how much should MERCOSUR 'pay' the EU for it to dismantle the ad valorem tariff or other components of its agricultural protection? The complexity of this problem increases as we go into a product-by-product negotiation. Different instruments protect different products but in general, ad valorem tariffs do not provide the bulk of protection to agricultural products. ${ }^{24}$

\footnotetext{
${ }^{23}$ Some products of important export value for the MERCOSUR also face sanitary and phytosanitary barriers some of which appear to be supported by weak scientific evidence.

${ }^{24}$ The nature of the complexity of EU agricultural protectionism can be seen in two examples. The first example is fruits such as pears, apples, oranges, etc. For specific periods of the year classified by month or consecutive months, fruits are protected by ad valorem and specific tariffs. Given the objective of protecting incomes of their farmers, the EUspecific tariffs vary inversely with the level of import prices. The result of this is that for pears, for example, there are 10 rates varying between 0 and $10.4 \%$. In addition, specific tariffs also vary by time of the year so that the number of possible combinations protecting pears is very high. In simulations performed by Argentina's Secretariat of Trade, the EU ad valorem tariff equivalent, including the effects of specific tariffs, protecting pears varies between 0 and $77 \%$. In other products like chocolates, protection varies according to product contents. Thus, protection for chocolates having $1 \%$ starch, $2 \%$ fat, $20 \%$ milk protein and $25 \%$ sugar, is defined in a table of codes. For chocolates filled with alcohol, the code number is 7161. In another table, this code number defines a specific tariff that has to be added to the corresponding ad valorem tariff. Different chocolates have different contents and there is a corresponding protection code for each one.
} 
(f) Furthermore, in contrast to the initial MERCOSUR proposal that did not exclude any product, the EU proposal excludes around 1000 tariff lines of which 781 are products of great export interest for Argentina. Estimates of the ad valorem equivalent by the Secretariat of Trade for a sample of the excluded products show a high average protection of $36 \%$ with a maximum of $463 \%$. Exclusion of these products significantly reduces the MERCOSUR export potential of a trade agreement with the EU.

(g) In addition to full access to the MERCOSUR goods markets, the EU is demanding (i) full reciprocity in textiles and footwear, (ii) standstill and rollback, (iii) for fisheries products, liberalization will take into account 'access to water resources', and (iv) duties on wine will be abolished in the framework of a separate agreement including 'protection of geographical indications and traditional expressions'. In Argentina, textiles and footwear are two 'sensitive' labor-intensive sectors. Standstill and rollback have not been discussed in detail but given the CAP, there is no way that a realistic rollback by the EU can offer gains in market access that could match a similar reform by the MERCOSUR. The details on access to water resources and intellectual protection for geographical indications have also not been specified but Argentina's national fishing fleet is not significant and, although it has good wines, it has not developed a tradition of 'geographical denominations'. Summing-up, reciprocal concessions in these areas of the expanded negotiating agenda appear to have much greater commercial value for the EU than for the MERCOSUR.

(h) In addition, the EU has demanded negotiations on government procurement and services where it seeks a high degree of access to the MERCOSUR markets. In services for example, it seeks access to all markets except audio- visual services, national maritime cabotage and air transport services. The proposal clarifies that the 'right of commercial presence' does “....not extend to seeking or taking employment in the labor market or confer a right of access to the labor market of another party" ${ }^{25}$ Regarding government procurement, the

${ }^{25}$ Quote taken from the EU document entitled 'European Union Working Text: Trade in Services', draft July 2, 2001. As a contrast, most ancestors of argentine nationals were Europeans and Argentina was, and by international standards remains, an open immigration country. Lindert and Williamson (2001) quantify the significant contribution of Argentina as a recipient country of European migration during, what they call, the first wave of globalization between 1870 and 1910. Rules on 'movement of persons' have certainly changed drastically. 
presumption is that EU multinationals are better positioned to sell to MERCOSUR governments than vice versa.

\subsubsection{Interpreting the EU proposal}

The difference in market access offered by the MERCOSUR (free trade) and EU proposals is so big that one wonders what are the underlying goals of the latter. For the MERCOSUR the goal has been a free trade agreement, while for the EU it has been a mercantilist agreement. However, this mercantilism is so unreasonable that under normal conditions no country or group of countries should take more than minimal resources to reject it. Why did the EU present such an offer?

One interpretation is that, given the bad economic situation of the MERCOSUR region, the EU concluded that it has a chance of walking away with a trade agreement in favor of its exporters without its importcompeting industries having to 'pay the costs'. A second interpretation is that the EU is not really interested in reaching a trade agreement with the MERCOSUR and that when it presented its proposal in the July meeting, it was simply filling a diplomatic formality. A third possibility is that the proposal represents a negotiating tactic and this is in fact what the MERCOSUR has concluded and in line with this, it has agreed to continue negotiating. This state of affairs did not change during the sixth and seventh meeting of the BNC, this last one held in April 2002.

\subsubsection{Illustrating the working of the handicaps}

Since the July meeting, some events have taken place that illustrate how the handicaps listed in Section 12.4 are working in the MERCOSUR-EU negotiations. First, preparing a counter-offer to the EU proposal requires a high degree of coordination between the public and private sectors. This is needed, for example, to determine in which of the possible timetables for tariff dismantling that have been decided on a preliminary basis $(0,4,7$ and 10 years), each product should be included. Both the public and private sectors have shown not to be well prepared for this exercise.

Second, as argued in Section 12.5.4, the discussion within the MERCOSUR, has also led to differing interpretations of the EU proposal. Thus, while Argentina and Brazil have in general maintained a critical stance, Uruguay remains an enthusiastic supporter of the EU offer. As said in Section 12.5.4, Uruguay expects more from a product-by-product negotiation than do Argentina and Brazil.

Third, within Argentina, there have been inter-agency differences. While the trade negotiators want to maintain a strong stance vis-à-vis 
the EU, others in government fear that this would be risking an 'important opportunity for the country'.

Fourth, the European lobby has been aggressive in pressing MERCOSUR. This lobby includes visits to the region by Mr. Pascal Lamy and Mr. Fischler. For example, Mr. Fischler, the EU agricultural commissioner, has been quoted as saying that the EU "...has shown to be a good client and friend of MERCOSUR..." as it has presented an ample offer to liberalize agricultural trade. Furthermore, the EU ".... is waiting a constructive counter-offer", and "...it is seeking to arrive at a balanced agreement...". ${ }^{26}$ Quite sarcastic.

Finally, there is little if no knowledge of possible economic impact in practically all of the subjects that have been put on the table by the EU. Except for some aggregate estimates of economic impacts for liberalizing trade in goods, there is no knowledge regarding the possible effects of negotiating reciprocal concessions with the EU in services, government procurement, geographical denominations, access to fishing waters, etc.

\subsubsection{Summing-up}

The MERCOSUR- EU negotiations represent an example of a negotiation where on one side of the table are developing countries with their handicaps and on the other side are trading partners with clout that know very well what they want from the agreement, i.e. an example of an 'unequal exchange' negotiation leading most likely to an unbalanced outcome. While MERCOSUR entered this negotiation candidly expecting to arrive at a free trade agreement, this never appears to have been the goal of the EU. Instead, this goal is for a highly mercantilist agreement of little economic value in relation to what MERCOSUR could internalize in a reciprocal and mutually beneficial agreement. The apparent strategy of the EU has been to take the MERCOSUR to negotiate on a product-by-product basis: "I give you minimal concessions and the honor of having completed a negotiation with the EU, and you give me your markets. This is a fair deal". I believe that the only way that MERCOSUR could conclude a reasonable negotiation is by standing firm on its initial proposal of negotiating a free trade agreement on the basis of clear principles and transparent instruments.

\footnotetext{
26 'Intenta la UE negociar sobre agricultura', La Nación October 4, 2001.
} 


\subsection{Drawing some lessons}

The Uruguay Round opened a divide in the trading system in such a way that we can talk of the 'before' and 'after' it. The GATT trading system, in which developing countries did not participate much, was more transparent and balanced than the WTO system. In the old system, the weaker countries could feel quite assured that the hegemonic countries would not make an abuse of their power. This appears to be no longer the case and now differences in resources, experience, managerial capacity, knowledge, and negotiating strength matter. This matters not only in multilateral negotiations but also in regional negotiations involving developed and developing countries. Differences in these factors are so important that sitting both groups of countries together in international trade negotiations is likely to generate an 'unequal exchange process' that results in unbalanced outcomes with costs to developing countries and the trading system. This analysis indicates some suggestions.

\subsubsection{Principles in trade negotiations}

It would appear that one way of modifying at least partly the outcome of these negotiations, would be to go back to respect the fundamental GATT principle, now included in the WTO, of negotiating on the basis of reciprocity and mutual benefits. Who should ensure that this basic principle is respected? The answer is that it is up to the developing countries to defend their interests which takes me to a second suggestion.

\subsubsection{Blocking negotiations: a defensive strategy}

This one is borrowed from Mike Finger in a personal communication: "Developing countries have to have the courage to insist that all reasonable doubt as to the economic effects of a proposed agreement be removed before they allow a decision to be approved". This is a defensive strategy that, if repeated every time there is 'reasonable doubt', might eventually generate forces in favor of rebalancing the odds in trade negotiations.

\subsubsection{Managementarrangements, knowledge and other domestic reforms}

In addition to 'blocking', developing countries should look into their negotiating arrangements. In some, there appears to be room for improving the management and skills allocated to the negotiations. They can also increase their internal cohesiveness by inter alia, strengthening the public sector-private sector consultation process. Additionally, with relatively 
few resources, developing countries can gain greater knowledge on net gains associated with reciprocal negotiations in the different areas of the agenda. These are some suggestions which I think would strengthen the negotiating capacity of developing countries.

\subsubsection{Congressional oversight}

I have argued that many countries are ill equipped for meeting the challenges of trade negotiations successfully and this implies that they are assuming risks that are higher than necessary. In these circumstances, as is the case in the US, the Congress of developing countries could assume the responsibility of providing an oversight function to ensure that the negotiations undertaken by the Executive Power are balanced and, in fact, result in a mutually beneficial exchange of concessions for their countries. Such an oversight role would hopefully result in a better outcome and would also strengthen the negotiating positions of developing countries vis-à-vis developed countries' trading partners.

\subsubsection{Aggressive unilateralism}

Regarding the trading system, the 'implementation problem' encountered by many developing countries is the result of the 'unequal exchange' in the Uruguay Round negotiations where industrial countries knew with a high degree of precision what they were signing and developing countries often did not have a clue. One message of this chapter is that if these types of exchanges are not rebalanced, the trade negotiations will continue generating 'implementation and other problems'. In this regard, one salient characteristic of the Uruguay Round negotiations was the presence of 'aggressive unilateralism'. We live in a new world where the strengthening of core economic interlinkages between countries, are a core ingredient of successful diplomacy. These interlinkages are also built in trade negotiations but if these are to be successful, aggressive unilateralism must go and give room to a constructive dialogue between countries in different development stages. This dialogue should be open enough to define agendas of interests to all countries without the presence of a big stick.

\subsubsection{Learning more about decision mechanism}

Ever since the completion of the Uruguay Round, well-intentioned researchers, politicians and other people of influence have been suggesting ways of 'fixing' the trading system. This research has uncovered many problem areas that have led to several reform proposals. If the hypothesis 
of this chapter is correct, the suggestion is to take this research one step back and ask what elements of our decision-making mechanisms explain why the system evolved from negotiations with reciprocity and mutual benefits, to 'unequal exchange negotiations'. I believe we need to get a better grasp of this if we want to make suggestions for lasting reforms to the nature of negotiations. On the developing country side, I have supported my thesis of 'unequal exchange' by looking into some of the elements that characterize the decision process of a few developing countries. It is crucial for this research to incorporate industrial countries as well. We need to enquire, for example, about the underlying forces that explain why these countries have been moving away from the basic GATT principles they once created and protected. Is, for example, the process of 'buying the votes for fast track' important for explaining the expansion of the trade negotiating agenda?

\subsection{7. 'Smoke and mirrors' of trade negotiations versus unilateral reforms}

For some developing countries, the potential gains to be achieved by participating in international trade negotiations are very high. This comes out very clearly for efficient agricultural producers. Because of these gains, many developing countries appear to be paralyzed by the promise of these negotiations and may have put aside unilateral reforms. Nevertheless, developing countries must learn to see behind the 'smoke and mirrors' of these negotiations.

The lesson here is that in the absence of reforms to the process of multilateral trade negotiations, the priorities of these alternative strategies have to be reassessed. Many developing countries have to assume that they will gain little in this process and put unilateral reforms again as national priorities. Developing countries should continue implementing all the necessary liberalization reforms supported by their societies, but they should consider binding in the WTO only those that bring clear economic gains. Binding additional concessions, as many did in the Uruguay Round, should be considered only in the event of clear reciprocity.

\section{Acknowledgements}

I want to express my gratitude to J. Michael Finger for more than 20 years of sharing ideas and suggestions that have helped me to understand with greater precision how the political economy forces operate to influence for the good and bad, unilateral and multilateral trade policies. I am also grateful to comments received from participants at the Conference on 
the 'The Political Economy of Policy Reform' where this chapter was presented.

\section{References}

Bhagwati, J. and H. Patrick (1990), Aggressive Unilateralism: America's 301 Trade Policy and the World Trading System, Ann Arbor, MI: University of Michigan Press.

Blackhurst, R., A. Enders and J. Francois (1996), "The Uruguay Round and market access: opportunities and challenges for developing countries”, pp. 125 - 155, in: W. Martin and L. Winters, editors, The Uruguay Round and the Developing Countries, Cambridge: Cambridge University Press.

Blackhurst, R., B. Lyakurwa and A. Oyejide (1999), Improving African Participation in the WTO, Washington, DC: The World Bank, Mimeo.

Casaburi, G. and C. Sánchez (2000), Las Distorsiones de los Mercados Mundiales de Alimentos y su Impacto en la Argentina, Buenos Aires: Fundación Mediterránea.

Dam, K. (2001), The Rules of the Global Game, Chicago: The University of Chicago Press. Finger, J. and J. Nogués (2002), The Unbalanced Uruguay Round Outcome: New Areas in Future WTO Negotiations, The World Economy, March 2002, Vol. 25, pp. 321 - 340, Oxford: Blackwell Publishing.

Finger, J. and L. Schuknecht (1999), Market Access Advances and Retreats: The Uruguay Round and Beyond, Washington, DC: World Bank, Mimeo.

Finger, J. and P. Schuler (2000), Implementation of Uruguay Round Commitments: The Development Challenge, The World Economy April 2000, Vol. 23, pp. 491 - 510, Oxford: Blackwell Publishing.

Grandes, M. (2001), External Solvency, Dollarisation and Investment Grade: Towards a Vicious Circle?, Technical Papers No. 177, Paris: OECD.

Hathaway, D. and M. Ingco (1996), "Agricultural liberalization and the Uruguay Round", pp. 30 - 58, in: W. Martin and L. Winters, editors, The Uruguay Round and the Developing Countries, Cambridge: Cambridge University Press.

Hoekman, B. (1996), “Assessing the general agreement on trade in services”, pp. 88-124, in: W. Martin and L. Winters, editors, The Uruguay Round and the Developing Countries, Cambridge: Cambridge University Press.

Hufbauer, G. and K. Elliot (1994), Measuring the Costs of Protection in the United States, Washington, DC: Institute for International Economics.

Lindert, P. and J. Williamson (2001), Globalization: a long history, Paper prepared for the Annual Bank Conference on Development Economics, The World Bank, Europe Conference.

Mossinghoff, G. (1987), Public Policy Challenges to the Pharmaceutical Industry, Pharmaceutical Manufacturers Association Review.

Mussa, M. (2002), Argentina and the Fund: From Triumph to Tragedy, Washington, DC: Institute for International Economics.

Nogués, J. (1985), "Distortions, factor proportions and efficiency losses: Argentina in the Latin American scenario", Weltwirtschaftliches Archive, Vol. 121, pp. 280 - 303.

Nogués, J. (1993), Social costs and benefits of introducing patent protection for pharmaceutical drugs in developing countries, The Developing Economies XXXI-I, Japan, March. 
Nogués, J. (2001), "Los resultados de la rueda Uruguay: consecuencias para la Argentina", pp. $105-239$, in: J. De Pablo, R. Dornbusch and J. Nogués, editors, La Globalización y Cada Uno de Nosotros, Buenos Aires: Consejo Empresario Argentino.

Nogués, J. (2002), Reciprocity in the FTAA: The Roles of Market Access, Institutions and Negotiating Capacity, INTAL-ITD-STA Working Paper SITI-02, Buenos Aires: InterAmerican Development Bank.

Nogués, J. and M. Grandes (2001), "Country risk: economic policy, contagion effect or political noise?", Journal of Applied Economics, Universidad del CEMA, Buenos Aires.

Odell, J. (2000), Negotiating the World Economy, Ithaca, NY: Cornell University Press.

OECD (2001), Agricultural Policies in OECD Countries: Monitoring and Evaluation, Paris: OECD.

Sánchez, G. (2001), La Inserción de la Argentina en la Economía Global, Buenos Aires: Fundación Mediterránea.

World Intellectual Property Organization (1988), Existence, Scope and Form of Generally Internationally Accepted and Applied Standards/Norms for the Protection of Intellectual Property, WO/Inf 129, Geneva: WIPO.

World Trade Organization (2000), Trade Policy Review of the European Union, WT/TPR/S/ 72, Geneva: WTO.

World Trade Organization (2001a), Ministerial Declaration, WT/MIN(01)/DEC/1, Geneva: WTO.

World Trade Organization (2001b), Implementation-related Issues and Concerns, WT/ $\operatorname{MIN}(01) / D E C / 17$, Geneva: WTO. 